\title{
KONTRIBUSI USAHA TUMPANGSARI KEDELAI ERHADAP PENDAPATAN KELUARGA PETANI KEDELAI DI SENTRA PRODUKSI JAWA BARAT
}

\section{Eti Suminartika, M. Arief Budiman, Nursyamsiyah, dan Kuswarini Kusno}

Fakultas Pertanian Universitas Padjadjaran

Email: eti.suminartika@unpad.ac.id

\begin{abstract}
ABSTRAK
Kedelai merupakan bahan pangan yang menduduki posisi strategis, ketergantungan impor kedelai berdampak kurang baik untuk menjaga keamanan pangan, karena impor kedelai menyedot devisa negara, dan adanya kerawanan pasokan jika penurunan nilai tukar rupiah, akibatnya berdampak pada kesetabilan harga kedelai nasional. Oleh karena itu diperlukan upaya megembangkan kedelai lokal yang didukung oleh petani. Tujuan penelitin ini untuk menganalisis peranan usahatani kedelai tumpangsari terhadap pendapatan keluarga tani. Penelitian dilaksanakan di sentra produksi kedelai Jawa Barat. Metoda yang digunakan adalah metoda survey, data yang digunakan terdiri data primer (dari petani) dan data secunder. Data dianalisis menggunakan analisis matematik dan deskriptif. Hasil penelitian menunjukkan, usahatani kedelai tumpangsari memberikan kontribusi cukup besar terhadap pendapatan petani. Selain itu tanaman tumpangsari (non kedelai) memberikan pendapatan tambahan, pendapatan berkelanjutan dan turut menjaga kegagalan usahatani.
\end{abstract}

Kata kunci: kedelai, tumpangsari, pendapatan, Jawa Barat.

\section{ABSTRACT}

Soybean is a food that occupies a strategic position, dependence on soybean imports has a bad impact on maintaining food security, because soybean imports suck up foreign exchange, and the supply of insecurity if the rupiah exchange rate decreases, consequently impacts on national soybean price stability. Therefore, an effort is needed to develop local soybeans supported by farmers. The purpose of this research is to analyze the role of intercropping soybean farming on the income of farmer families. The research was conducted at the West Java soybean production center. The method used is the survey method, the data used consists of primary data (from farmers) and secondary data. Data were analyzed using mathematical and descriptive analysis. The results showed that intercropping soybean farming contributed significantly to farmers' income. In addition, intercropping (non-soybean) crops provides additional income, sustainable income and helps maintain farm failure.

Keywords: soybean, policulture, West Java Income

\section{PENDAHULUAN}

Kedelai sumber bahan pangan utama bagi masyarakat Indonesia. Konsumsi kedelai terus meningkat, kenaikan permintaan kedelai disebakan peningkatan konsumsi per capita dan peningkatan jumlah penduduk. Pada tahun 1970, konsumsi per capita kedelai hanya 3,7 $\mathrm{kg} / \mathrm{cap} / \mathrm{tahun}$, saat ini telah mencapai lebih dari $11,5 \mathrm{~kg} / \mathrm{cap} / \mathrm{tahun}$ (Kementrian Pertanian, 2016).

Sebanyak 60 persen dari supply kedelai digunakan untuk konsumsi dalam pembuatan tahu dan tempe karena kedelai di Indonesia merupakan sumber protein kedua setelah ikan.
Kedelai menyumbang 10 persen kebutuhan protein masyarakat Indonesia. Lebih jauh harga kedelai merupakan sumber protein murah dan terjangkau masyarakat. Dengan demikian kedelai memegang peranan penting untuk ketahanan dan keamanan pangan baik dari segi kuantitas maupun kualitas.

Untuk menjaga ketahanan pangan, dari segi kuantitas, maka domestik supply harus dipelihara. Pada kenyataanya impor kedelai diatas produksi nasional, sekitar 60 persen kedelai berasal dari impor dan 40 persen berasal dari produksi nasional (Kementrian Pertanian, 2016). Tingginya permintaan 
kedelai impor juga didukung oleh preferensi permintaan industri tahu dan tempe terhadap kedelai impor tersebut.

Menurut Suminartika (2012), pengrajin tahu menggunakan kedelai impor karena kontinuitas kedelai impor yang terjamin, sedangkan perajin tempe lebih memilih kedelai impor karena butirannya lebih besar, seragam dan berwarna kuning cerah, sehingga tempe yang di hasilkan lebih baik tampilannya.

Meskipun kedelai impor banyak digunakan oleh produsen tahu tempe (dengan komposisi sekitar $70 \%$ kedelai impor dan 30\% kedelai lokal) namun kedelai lokal memiliki banyak keunggulan. Kedelai lokal lebih fresh karena tidak terlalu lama disimpan, sehingga perajin tahu lebih suka menggunakan kedelai lokal. Kedelai lokal sendiri masih diperlukan sebagai perasa yang umumnya tidak ada pada kedelai impor. Kedelai lokal unggul dari impor untuk membuat tahu karena rasa tahu lebih lezat, rendemennya lebih tinggi (Suminartika, 2010).

Dengan demikian, kedelai lokal memiliki keunggulan tersendiri dari segi kualitas, namun dari segi kuantitas dan kontinuitas masih memerlukan perbaikan, oleh karena itu pengembangan produksi kedelai lokal perlu dikembangkan untuk mendukung pasokan bahan baku industri pengolahan kedelai, turut menjaga keamanan dan ketahanan pangan nasional.

Pengembangan usahatani kedelai akan berjalan secara berkelanjutan apabila petani memperoleh pendapatan yang memadai (menguntungkan). Untuk memperoleh keuntungan yang lebih baik, petani dalam melakukan usahatani kedelai selain dilakukan secara monokultur, mereka melaksanakan secara tumpangsari.

Permasalahan dalam penelitian adalah: (1) Bagaimankah pendapatan usahatani kedelai (2) seberapa besar kontribusi pendapatan usahatani kedelai sistim tumpangsari terhadap pendapatan keluarga

\section{KERANGKA TEORITIS}

Menurut (Soekartawi, 1995) biaya usahatani diklasifikasikan menjadi, yaitu:

- Biaya tetap total (Total Fixed Cost/ TFC) adalah biaya yang relatif tetap jumlahnya, dan terus dikeluarkan walaupun produksi yang diperoleh banyak atau sedikit, misalnya: sewa tanah, sewa gudang, pajak dan lainnya.

- Biaya variabel total (Total Variable Cost/ TVC) adalah biaya yang besar kecilnya dipengaruhi oleh produksi yang diperoleh, misalnya: biaya sarana produksi, upah tenaga kerja, biaya angkut, dan sebagainya.

Total biaya produksi adalah penjumlahan dari biaya tetap (fixed cost) dengan biaya tidak tetap (variabel cost), dapat ditulis dengan rumus sebagai berikut :

$$
\mathrm{TC}=\mathrm{TFC}+\mathrm{TVC}
$$

Keterangan :

$\mathrm{TC}=$ Total Pengeluaran (Rp)

TFC = Total Biaya Tetap (Rp)

TVC $=$ Total Biaya Variabel $(\mathrm{Rp})$

Penerimaan Usahatani. Penerimaan usahatani merupakan perkalian antara produksi yang diperoleh dengan harga jual dari total penerimaan kegiatan usahatani yang diterima pada akhir proses produksi. Peneri-maan usahatani dapat pula diartikan sebagai keuntungan material yang diperoleh seorang petani sebagai pengelola usahatani karena pemakaian barang modal yang dimilikinya. Rumusnya situlis sebagai berikut :

$$
\mathrm{TR}=\mathrm{PY} . \mathrm{Y}
$$

Keterangan :

$\mathrm{TR}=$ Total Penerimaan $(\mathrm{Rp})$

PY = Harga Produksi (Rp)

$\mathrm{Y}=$ Jumlah Produksi yang Dihasilkan

Pendapatan Usahatani. Pendapatan usahatani merupakan ukuran penghasilan yang diterima oleh petani dari usahataninya. Dalam analisis usahatani, pendapatan petani digunakan sebagai indikator penting karena merupakan sumber utama dalam mencukupi kebutuhan hidup sehari-hari. Pendapatan usahatani perupakan selisih antara penerimaan dengan biaya produksi, baik produksi yang tidak tetap maupun biaya produksi tetap.

Pendapatan merupakan balas jasa terhadap penggunaan faktor-faktor produksi yang digunakan dalam menjalankan usahatani (lahan, modal, tenaga kerja, dan pengelolaan). Soekartawi (1984) menjelaskan bahwa untuk mengukur pendapatan terdapat beberapa cara 
yaitu pendapatan tunai usahatani dan pendapatan bersih usahatani. Pendapatan bersih usahatani diperoleh dari selisih antara penerimaan tunai usahatani dan pengeluaran tunai usahatani. Penerimaan tunai usahatani didefenisikan sebagai nilai uang yang diterima dari penjualan produk usahatani. Pengeluaran tunai usahatani didefenisikan sebagai sejumlah uang yang dibayarkan untuk pembelian barang dan jasa bagi usahatani. Sedangkan untuk pendapatan bersih usahatani diperoleh dari selisih antara pendapatan kotor usahatani dan pengeluaran total usahatani. Dimana pendapatan kotor usahatani didefenisikan sebagai nilai produk total usahatani dalam jangka waktu tertentu, baik yang dijual maupun yang tidak dijual. Berikut adalah rumus total pendapatan :

$$
\mathrm{I}=\mathrm{TR}-\mathrm{TC}
$$

Keterangan :

I = Total Pendapatan (Rp)

$\mathrm{TR}=$ Total Penerimaan $(\mathrm{Rp})$

$\mathrm{TC}=$ Total Pengeluaran $(\mathrm{Rp})$

Penelitian dilaksanakan di sentra utama produksi kedelai Jawa Barat yaitu kabupaten Garut. Kecamatan sentra kedele kabupaten Garut yaitu berada di kecamatan Pangatikan.

\section{METODOLOGI}

Penelitian ini merupakan penelitian kuantitatif dengan teknik penelitian survei deskriptif. Menurut Sugiono (2010), penelitian survei adalah penelitian yang dilakukan pada populasi besar ataupun kecil, tetapi data yang dipelajari adalah data dari sampel yang diambil dari populasi tersebut.

Jenis data yang digunakan dalam penelitian ini adalah data primer dan data sekunder. Data primer merupakan data yang di peroleh dari responden dari hasil wawancara langsung. Data sekunder merupakan data pelengkap dari data primer. Data sekunder adalah di peroleh dari studi literature kepustakaan, dokumen instansi seperti Kantor Desa/kecamatan, Perpustakaan, Badan Pusat Statistik, Dinas Pertanian, jurnal dan media internet yang terhubung dengan Penelitian.

Penentuan responden petani menggunakan metoda random sampling. Jumlah sampel yang diambil didasarkan pada argumen: Semakin besar jumlah sampel, semakin mendekati keadaan sebenarnya. Menurut Gasperzs (1991) apabila peneliti tidak mengetahui ragam dari populasi (S) atau proporsi $(\mathrm{P})$ atau tidak dapat memperkirakannya, maka ukuran sampel (n) dapat diambil 5 persen, 10 persen dan 25 persen. Selanjutnya Gasperzs (1991), untuk ukuran contoh yang lebih besar dari 30 sampel maka sebaran data dalam contoh akan menyebar mendekati sebaran normal. Selain pertimbangan di atas, besaran sampel yang akan diambil di dasarkan pada ketersedian dana dan tenaga. Jumlah sampel yang diambil $12,5 \%$ dari populasi (jumlah populasi sekitar 240 petani) petani kedelai di kecamatan Pangatikan kabupaten Garut (sentara produksi kedelai di Jawa Barat), dengan demikian responden berjumlah 30 petani kedelai.

Operasionalisasi Variabel/Konsep.

Jumlah produksi adalah seluruh produksi manggis petani dalam satu musim panen. Jumlah produksi dinyatakan dalam $\mathrm{kg}$.

Harga Jual adalah sejumlah uang yang diterima petani dari penjualan manggis dinyatakan dalam rupiah per kilogram.

Biaya tetap adalah biaya yang besar kecilnya tidak dipengaruhi oleh perubahan jumlah produksi. Biaya tetap meliputi biaya pajak dan penyusutan alat. biaya tetap ada yang tunai dan non tunai. Dinyatakan dalam satuan rupiah.

Biaya variabel adalah yang besar kecilnya mempunyai pengaruh langsung pada hasil produksi manggis. Biaya variabel terbagi manjadi dua yaitu biaya variabel tunai dan biaya variabel (tunai dan non tunai). Biaya variable dinyatakan dalam rupiah.

Biaya total adalah jumlah biaya tetap ditambah biaya variabel. Biaya total terbagi manjadi dua yaitu biaya total tunai dan biaya total (tunai dan non tunai). Biaya total dinyatakan dalam rupiah.

Penerimaan adalah semua produk yang dihasilkan satu musim panen, yaitu merupakan perkalian hasil produksi manggis dengan harga jual per kilogram. Dinyatakan dalam rupiah.

Pendapatan Usahatani adalah pengurangan penerimaan dengan biaya total tunai. Dinyatakan dalam rupiah.

Keuntungan petani manggis (pendapatan bersih) adalah pengurangan penerimaan dengan biaya total (baik tunai maupun non tunai). Dinyatakan dalam rupiah. 
Pendapatan keluarga adalah

penjumlahan seluruh pendapatan yang

dipeoleh petani, meliputi pendapatan usahatani dan luar usahatani yang diperoleh dalam setahun. Pendapatan keluarga dinyatakan dalam rupiah.

Analisis Data. Analisis matematik digunakan untuk menganalisis usahatani kedelai sistim tumpangsari. Dari analisis tersebut akan dihitung biaya penerimaan, pendapatan petani dan keuntungan.

Analisis biaya meliputi biaya variabel, biaya tetap dan biaya total usahatani manggis. Biaya meliputi biaya tunai dan biaya non tunai (Sadono Sukirno, 1994). Biaya tetap ditambah biaya variabel disebut biaya total, atau secara singkat dapat di rumuskan sebagai berikut :

$$
\mathrm{BP}=\mathrm{BT}+\mathrm{BV}
$$

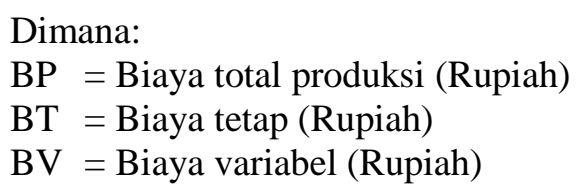

Dimana:

$\mathrm{BP}=$ Biaya total produksi (Rupiah)

$\mathrm{BT}=$ Biaya tetap (Rupiah)

$\mathrm{BV}=$ Biaya variabel (Rupiah)

Penerimaan adalah nilai penjualan kedelai yang dihasilkan satu musim panen, yaitu merupakan perkalian hasil produksi manggis dengan harga jual per kilogram, rumus penerimaan manggis adalah :

$$
\mathrm{TR}=\mathrm{Y} . \mathrm{Hy}
$$

Dimana :

$\mathrm{TR}=$ Penerimaan $(\mathrm{Rp})$

$\mathrm{Y}=$ jumlah produksi manggis $(\mathrm{kg})$

$\mathrm{Hy}=$ Harga jual manggis $(\mathrm{Rp} / \mathrm{kg})$

Pendapatan usahatani adalah pengurangan penerimaan dengan biaya total tunai dengan rumus:

$$
\mathrm{Pdp}=\mathrm{TR}-\mathrm{BP}
$$

Dimana:

$\mathrm{TR}=$ Penerimaan $(\mathrm{Rp})$

$\mathrm{BP}=$ Biaya produksi total (tunai) $(\mathrm{Rp})$

$\mathrm{Pdp}=$ Pendapatan petani $(\mathrm{Rp})$

Keuntungan petani kedelai (pendapatan bersih) adalah pengurangan penerimaan dengan biaya total (baik tunai maupun non tunai), rumus keuntungan adalah :

$$
\mathrm{Pd}=\mathrm{TR}-\mathrm{BP}
$$

Dimana:

$\mathrm{TR}=$ Penerimaan $(\mathrm{Rp})$

$\mathrm{BP}=$ Biaya prod total (tunai, non tunai)

$\mathrm{Pd}=$ Pendapatan petani $(\mathrm{Rp})$

Pendapatan keluarga petani kedelaia dalah penjumlahan seluruh pendapatan yang diperoleh petani, meliputi pendapatan usahatani dan luar usahatani yang diperoleh dalam setahun. Pendapatan keluarga dinyatakan dalam rupiah.

Kontribusi pendapatan usahatani kedelai adalah perbandingan antara pendapatan petani kedelai dengan pendapatan keluarga dikali 100 persen.

\section{HASIL DAN PEMBAHASAN}

Keadaan Petani dan Usahatani.

Keadaan umum responden petani kedelai sebagai berikut, rentang umur petani kedelai adalah 37-51 tahun, dengan rata -rata umur petani kedelai 49,3 tahun, dengan demikian umur petani kedelai merupakan golongan umur produktif. Pendidikan petani kedelai umumnya tamatan sekolah dasar atau memiliki pendidikan yang rendah, hal tersebut sejalan dengan Hayati dkk (2015), karakteristik petani lemah dengan pendidikan formal dan nonformal.

Keadaan lahan usahatani kedelai di kabupaten Garut, rata-rata luas lahan yang dimiliki petani sekitar 1,43 hektar, dimana sekitar 0,42 hektar merupakan usahatani kedelai, sedangkan rata-rata lahan kebun non kedelai seluas 0,87 hektar yang hanya diusahakan oleh 37 persen petani kedelai. Rata-rata luas lahan sawah petani kedelai 0,26 ha dan diusahakan oleh $88,6 \%$ petani kedelai, dengan demikian petani kedelai merangkap menjadi petani padi.

Lahan yang diusahakan oleh semua petani responden merupaka lahan milik sendiri. Mereka menggunakan lahan kebun untuk ditanami kedelai dan kebun campuran yang ditanami berbagai macam tanaman (tidak ditanami kedelai). Disamping lahan kebun, sebagian petani responden bahkan memiliki lahan sawah.

Sistim Tumpangsari. Sebelum menjabarkan sistim tumpangsari, pembahasan pola tanam dapat menunjang sistim tersebut 
dijalankan. Pola tanam dimaksudkan pola petani menanam laha usahataninya dalam kurun waktu satu tahun. Pola tanamnya yang dilakukan petani pada lahannya adalah Kedelai-kedelai-diberakan, adapun waktu tanamnya sebagai berikut:

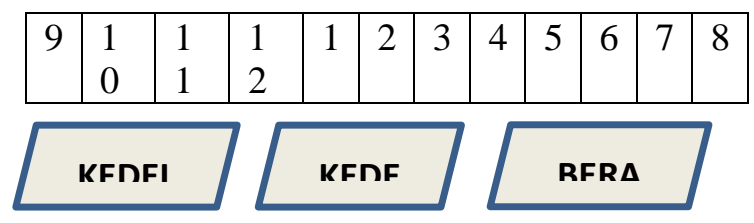

Gambar 1

Pola Tanam Usahatani Kedelai

Sistim tumpangsari dijalankan dengan dilakukan penanaman kedelai di bulan pertama, selanjutnya satu bulan kemudian ditanam jagung dan satu bulan kemudian ditanami cabai. Sistim tumpangsari seperti ini memberikan banyak manfaat; (1) menjaga kontinuitas pendapatan petani (2) mengurangi resiko gagal panen, (3) pemanfaatan sumberdaya (pupuk, obat, tenaga kerja, sinarmatahari, dll)

Analisis Usaha Tumpangsari. Berikut output dan input usahatani kedelai, hasil produksi tanaman kedelai cukup tinggi karena varietas yang ditanam petani merupakan varietas yang tingkat produktivitasnya tinggi yaitu kedelai varietas Argomulyo. Input yang digunakn petani berupa pupuk organik, pupuk kimia dan obat kimia terutama pembasmi jamur.

Hasil produksi kedelai petani adalah 890 kilogram per 0,42 hektar lahan. Kedelai dijual dengan harga 6.166 rupiah per kilogram atau menghasilkan nilai jual sebanyak 5.482.500 rupiah.

Tabel 1.

Penggunaan Bahan per 0,42 Hektar

\begin{tabular}{llll}
\hline Bahan & $\begin{array}{l}\text { Jml } \\
(\mathrm{kg})\end{array}$ & Harga & Nilai \\
\hline Bibit & 17,5 & 10.000 & 175.333 \\
Za & 77,0 & 2500 & 192500 \\
TSP & 54,2 & 2500 & 135666 \\
KCL & 26,6 & 3000 & 79900 \\
Insectisida & 0,7 & 25000 & 17500 \\
Fungisida & 3,2 & 85000 & 272000 \\
\hline Total & & & 1.030 .000 \\
\hline
\end{tabular}

Sumber: Data primer (diolah)
Penggunaan Tenaga kerja per 0,42 Hektar

\begin{tabular}{lll}
\hline Jenis tenaker & $\begin{array}{l}\text { Jumlah } \\
\text { HOK }\end{array}$ & $\begin{array}{l}\text { Nilai } \\
(\mathrm{Rp})\end{array}$ \\
\hline Ngolah tanah & 11,4 & 573.334 \\
Nanam & 3,2 & $98.333,3$ \\
Ngored & 14,9 & $456.33,0$ \\
Mupuk & 1,8 & $90.000,0$ \\
HPT & 1,8 & $154.999,0$ \\
Panen & 9,9 & $558.666,0$ \\
Angkut & 1,6 & $81.666,7$ \\
Jemur & 2 & $100.000,0$ \\
\hline Total & & 2.013 .33 .0 \\
\hline Sumber: Data primer (diolah) &
\end{tabular}

Sumber: Data primer (diolah)

Nilai penjualan tersebut selanjutnya dikurangi biaya bahan, biaya tenaga kerja dan biaya tetap seperti yang terlihat di Tabel 1 dan Tabel 2. dari selisih nilai penjualan dengan biaya maka diperoleh keuntungan usahatani kedelai sebesar 2.438.767 rupiah.

Petani menanam kedelai sebanyak dua kali dalam setahun, dengan demikian mereka mendapatkan keuntungan sebesar 4,8 juta rupiah per tahunnya. Seperti yang diuraikan sebelumnya, usahatani kedelai merupakan usahtani tumpangsari dengan tanaman jagung, cabai, tembakau. Tabel berikut menjelaskan tanaman lainnya disamping tanaman kedelai di kebun petani. Ternyata umumnya petani menanam jagung bersamaan dengan kedelai.

Tabel 3.

Jumlah Petani Tumpangsari

\begin{tabular}{lll}
\hline Usaha & $\begin{array}{l}\text { Jml } \\
\text { petani }\end{array}$ & Persen \\
\hline Kedelai & 30 & 100 \\
Jagung & 26 & 87 \\
Cabai & 11 & 37 \\
Tembakau & 4 & 13 \\
Non pertanian & 33 & 33 \\
\hline Sumber: Data prim
\end{tabular}

Sumber: Data primer (diolah)

Tabel 4.

Pendapatan Petani

\begin{tabular}{lll}
\hline Sumber pendapatan & jumlah & $\begin{array}{l}\text { Persen } \\
(\%)\end{array}$ \\
\hline Usahatani kedelai & 4.877 .534 & 15,7 \\
Usaha tumpangsari & 19.328 .199 & 62,1 \\
Usaha non kedelai & 6.900 .000 & 22,2 \\
Pendapatan keluarga & 31.106 .533 & 100,0 \\
\hline
\end{tabular}

Sumber: Data primer (diolah)

Tabel 2. 
Kontribusi Pendapatan. Pendapatan tumpangsari sebanyak 24205733, tanaman kedelai hanya memberikan kontriusi 20,1 persen (4.877.534), sementara selain tanaman kedelai di kebun kedelai tersebut memberikan kontribusi pendapatan yang jauh lebih besar yaitu 79,9\% (19.328.199)

Kontribusi usahatani kedelai dan usaha tanaman tumpangsari terhadap pendapatan keluarga disajikan di Tabel. Dari tabel terlihat bahewa usaha tani kedelai hanya memberikan kontribusi 15,7 persen, sedangkan usahatani tumpangsari kedelai (kedelai dan tanaman lainnya) memberikan kontribusi 77,8 persen

\section{KESIMPULAN}

Usahatani tumpangsari kedelai memberikan kontribusi pendapatan yang cukup besar terhadap pendapatan keluarga, sementari usahatani kedelai murni kontribusinya tidak begitu besar, namun tanaman tumpangsari (non kedelai) memberikan pendapatan tambahan, pendapatan berkelanjutan dan turut menjaga kegagalan usahatani.

\section{DAFTAR PUSTAKA}

Erniawan Hadi, Juanda B dan Rustiadi, E. 2015. Analisis Kinerja Ketahanan Pangan di Propinsi NTB.

Sosiohumaniora. Vol 17 (2) 119-135.

Kementrian Pertanian (2016). Statistik Tanaman Pangan. Kementan. Jakarta. Gaspez, Vincent. (1991). Tehnik pengambilan Contoh untuk Penelitian Survei. Tarsito, Bandung.

Hayati, Amanah Siti, Vitalaya Aida dan Prabowo (2015). Kemampuan Perempuan Tani dalam Mendukung Ketahanan Pangan Rumah Tangga. Sosiohumaniora. Vol 17 (3) $29-235$.

Matakena, Simon. 2012. Efisiensi penggunaan Faktor-Faktor Produksi Guna Meningkatkan Produksi Usahatani Kedelai di Distrik Makimi Kabupaten Nabire. Jurnal Agribisnis Kepulauan, Vol 1(1) 43-60

Mufriantie, Fithri dan Anton. 2014. Analisis Faktor Produksi dan Efisiensi Alokatif Usahatani Bayam (Amarathus sp) Di
Kota Bengkulu. Jurnal AGRISEP Vol 15 (1) 31-37

Muzdalifah. 2011. Analisis Produksi dan Efisiensi Usahatani Padi di Kabupaten Banjar. Jurnal Agribisnis Perdesaan Vol 1 (4) $40-49$

Soekartawi. 2003. Agribisnis Teori dan Aplikasinya. Jakarta: Cetakan ke-7, Raja Grafindo Persada.

Suminartika, Eti (2010). Kemampuan Perajin (Tahu-Tempe) di Kabupaten Sumedang dalam Mengembangkan Usaha. LPPM UNPAD, Bandung.

Suminartika (2012). Productivity of Soybean Farming in Indonesia. Proceeding: Producer Agency in the Global Market. Unpad, Bandung 
Vol. 2, No. 2, Desember 2017: 291-357 AGRICORE-Jurnal Agribisnis dan Sosial Ekonomi Pertanian 